\title{
Spatial distribution of heathlands in the north-western part of Poland (Pomerania District)
}

\author{
*Mieczyslaw Kunz, **Andrzej Nienartowicz \\ * Department of Cartography, Remote Sensing and GIS, Institute of Geography, \\ ** Laboratory of Ecological Processes Modelling, Institute of Ecology and Environment Protection, \\ Faculty of Biology and Earth Sciences, Nicolaus Copernicus University, Gagarina 9, 87-100 Torun, Poland \\ e-mail: met@umk.pl, nienart@umk.pl
}

\begin{abstract}
Spatial distribution of heathlands in Pomerania (the north-western part of Poland) was described based on the results of questionnaires sent out to the registered offices of all forest divisions (96), national (4) and landscape (15) parks of this area. According to the inventory, heathlands occur in 28 forest divisions and 3 national and landscape parks. The frequency of occurrence and the area covered by heathlands were determined. All the data were compiled in the form of a spatial database with the use of Geographic Information Systems. The paper also contains the geographical distribution of heath habitats in the area of Pomerania according to particular syntaxa. Additionally, the content of the database CORINE Land Cover was analysed at the third level for the area of Pomerania, completed for the years of 2000 and 2006. The area and the number of patches were described according to three land cover categories: heaths (code 322), conflagration sites (code 334) and peat bogs (code 412).
\end{abstract}

\section{Introduction}

Heathlands play an extremely significant role in the landscape. More and more often they constitute the subject of researches and analyses performed with different methods and modern research tools, often combining different methodological approaches and science disciplines or specialities. And thus, they are included within the range of detailed interests of not only botanists, biologists and ecologists, but also geographers, urban planners and historians. The importance of this vegetation formation is proved by the fact that they were included on the European list of Natura 2000 based on the Habitat Directive. In Pomerania, similarly like in other regions of Poland, there are not many sites with heath formations occurring over large areas, except for special areas - military training grounds. Heaths usually occur as smaller clusters of patches. They are a frequent element of a landscape with electrical power lines, section lines, firebreaks and often small forest glades.
Due to the fact that heaths are present mainly in a forest landscape, therefore they are under the administration of forest divisions or national parks and landscape parks.

The present paper aims at making a spatial inventory of the occurrence of heaths in the region of Pomerania, based on questionnaires filled in by headquarters of forest divisions, as well as national and landscape parks of this area. Additionally, the locations of heather known from the literature and from available databases were described.

\section{The study area}

The studies on the spatial distribution of heaths were conducted in Pomerania (Słowiński and Pomeranian Lake Districts). The range of the analyzed area covers the West Pomerania province and most of the Pomerania province, part of the Kujawy-Pomerania province, as well as fragments of the Wielkopolska and Lubuskie provinces. The 
study area of almost $50,000 \mathrm{~km}^{2}$ is enclosed within natural boundaries: the Odra River on the western side, the coast of the Baltic Sea in the North, the Vistula River in the East, and the Warta and Notec Rivers in the South (Fig. 1). According to CORINE Land Cover 2006, agricultural lands $(55 \%)$, as well as forests and semi-natural ecosystems $(40 \%)$ dominate in this area. The relief of this area is characterized by considerable spatial heterogeneity, although the whole region was "united" by the homogeneous morphogenetic cycle during the Pomeranian stadial of the Baltic glaciation (Augustowski 1977).

The delimited area is administered by 96 forest divisions, which are included within five Regional Directorates of State Forests - in Szczecin, Szczecinek, Gdańsk, Torun and Piła.

Despite heavy transformations of forest plant communities and intensification of agricultural economy, the nature of this area is characterized by high qualities, and therefore 4 national parks were delimited (Woliński, Słowiński, Drawieński, Tuchola Forest) and 15 landscape parks (Fig. 3).

\section{Research methods}

In the research on the spatial distribution of heaths, the survey method was applied. A questionnaire was sent to headquarters of all forest divisions, as well as to directorates of national and landscape parks of this area. The compiled questionnaire includes a detailed inquiry about the occurrence of heath formations in the area are under the administration of a given unit of economy or nature conservation. The inquiry concerns the name of a given heath site (if any), its location in the division into forest districts, forest sections and subsections, geographical coordinates of a contour of this site, its surface area, land use categories, as well as dominant or characteristic plant species. Moreover, the questionnaire also includes contact data of a person who filled it in.

In the spatial location of the questionnaire results, the software for the development of spatial databases was applied - ArcView 9.3 by the company ESRI. Based on the cartographic sources collected in the digital form - topographic maps and forest economic maps, the localization and entering into the system of catalogued heath areas were completed, whenever possible with reference to boundaries of a patch or a subdistrict. In the study, tools of geoinformatics and remote-sensing data were applied, which were proposed and described by Veitch et al. (1995).

In the description of the geographical distribution of heath habitats occurring in Pomerania, according to particular syntaxa, "Guide book to protection of habitats and species of Natura 2000" was used, edited by J. Herbich in 2004, as well as other selected literature references.
Additionally, the content of the database CORINE Land Cover at the third level was analyzed for this area. The database CORINE Land Cover (CLC), which covers the whole country, was compiled based on the interpretation of satellite images LANDSAT ETM+ for the year 2000 and SPOT-4 HRVIR, as well as IRS P6 LISS III for the year 2006. It is a database presenting the land cover classified according to 44 categories, with the smallest -25 ha distinguished section of the area (Ciołkosz and Bielecka 2005; Bielecka 2007). Among all the distinguished land cover categories of the third level, areas dominated by $\mathrm{Cal}$ luna vulgaris and with the occurrence of other low shrubs, shrubs and wilding trees, are defined as heaths and bushes (code 322), peat bogs (code 412) and conflagration sites (code 334).

\section{Results}

\subsection{Geographical distribution and types of heath habi- tats in Pomerania}

Based on the "Guide book to protection of habitats and species of Natura 2000" (Herbich ed. 2004), heaths occurring in Pomerania can be classified within the following types of natural habitats:

- 4010 wet heaths with cross-leaved heath Erica tetralix, which occur in the northern part of Pomerania, mainly in the Forest of Goleniów, in the vicinity of Kołobrzeg and in the northern part of the Drawskie Lake District (Fig. 2a); they dominate in places with extensive grazing, turf removing and periodic burning off, as well as in places with former exploitation of acid peat and wet drainless depressions in the coastal zone; the distribution of wet heaths is hardly explored, so far they were described in the following studies: Herbichowa (1979), Jasnowski (1962a, 1962b), Jasnowski et al. (1968), as well as Piotrowska and Herbich (1974); this habitat occurs in Poland as one subtype: 4010-1 wet heaths with cross-leaved heath Erica tetralix (Fig. 2b); according to Nienartowicz and Kunz (2003) wet heaths occur in Pomerania near the towns of Puck (Bielawskie Błoto), Szczecin and Goleniów (the Sowno heathland), as well as in the nature reserve Nowe Wicko;

- 4030 dry heaths (Calluno-Genistion, Pohlio-Callunion, Calluno-Arctostaphylion) occur within the whole area of Pomerania (Fig. 2c), from small dense patches on the edges of deciduous and coniferous forests to extensive sandy areas on military training grounds; they were described e.g. in the studies by Brzeg (1982), Czubiński (1950), Gawłowska (1964) and Werdyn (1964); their coastal forms were presented by Markowski (1997); according to Nienartowicz and Kunz (2003), in Pomerania dry heaths occur in the vicinity of the Słowiński National Park, near the towns of Jastrzębia Góra and Władysławowo, Szc- 


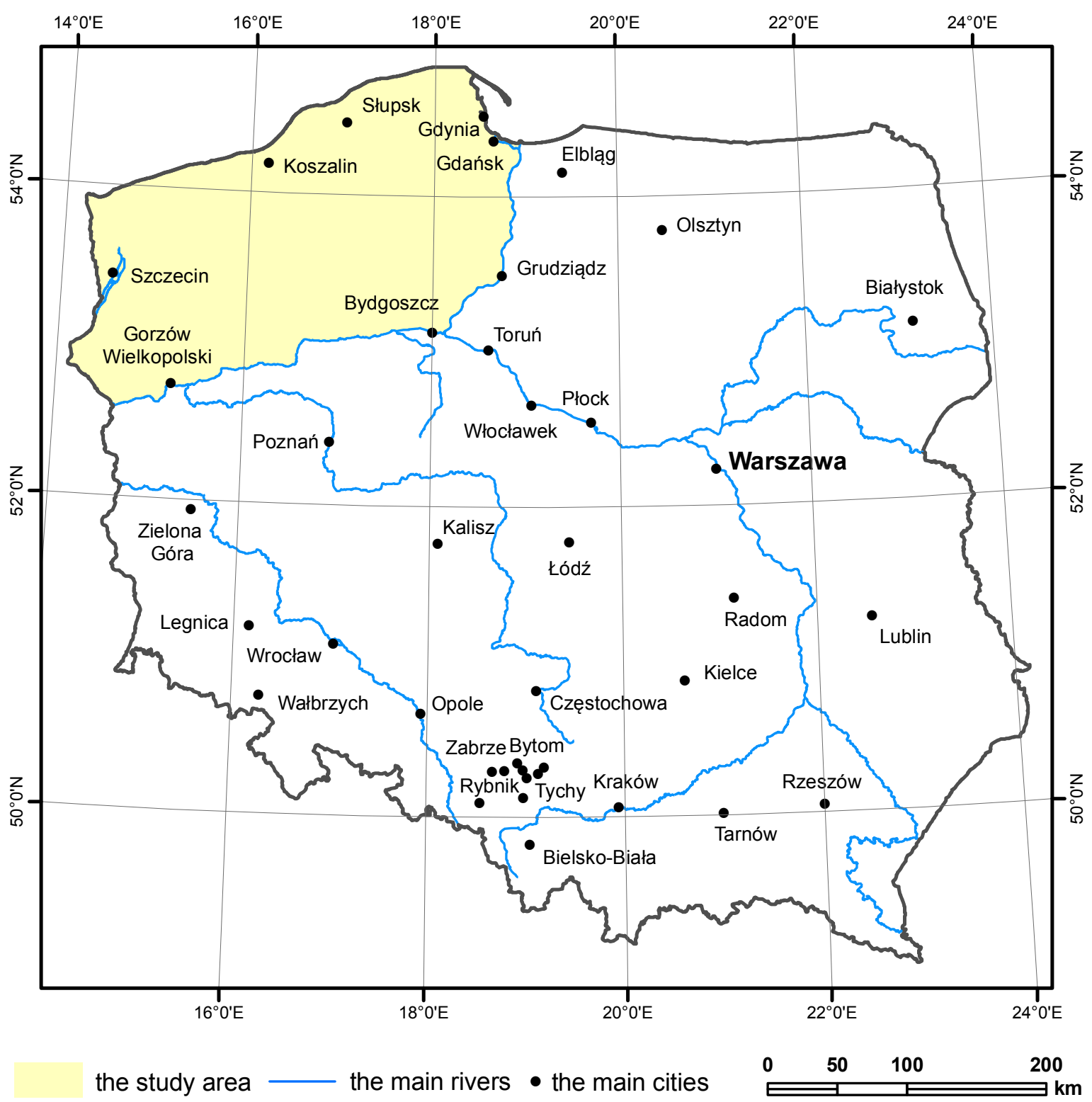

Figure 1. Location of the study area (Pomerania) in Poland

zecinek, Borne Sulinowo and Okonek, as well as in the Tuchola Forest;

this habitat is divided into three subtypes:

- 4030-1 Genista heaths Calluno-Genistetum (Fig. 2d) occur mainly along forest margins, roads and communication routes, as well as firebreaks; in Pomerania they were recorded in the Drawski Forest, as well as between the towns of Mirosławiec and Czaplinek; so far they were not studied in details and in the territory of Poland their range of occurrence reaches its eastern borderline,

- 4030-2 heaths with Pohlia nutans Pohlio-Callunetum (Fig. 2e) cover large areas mainly in the military areas; they occur along forest peripheries, insolated escarpments, electrical power lines and firebreaks; they are included among the most frequently encountered types of heaths; in Pomerania they occur in the dense form in the northern part of the Drawski Forest and in the South Pomeranian Lake District, as well as in the scattered form in the Notec Forest, the Drawski Forest, the Gorzów Valley, the Myślibórz Lake District and the Tuchola Forest (Kunz et al. 2008)

- 4030-3 bearberry heaths Arctostaphylo-Callunetum (Fig. 2f) occur along the edge of pine forests, along roads and communication routes; their area of occurrence is small; they occur in the Tuchola Forest. 


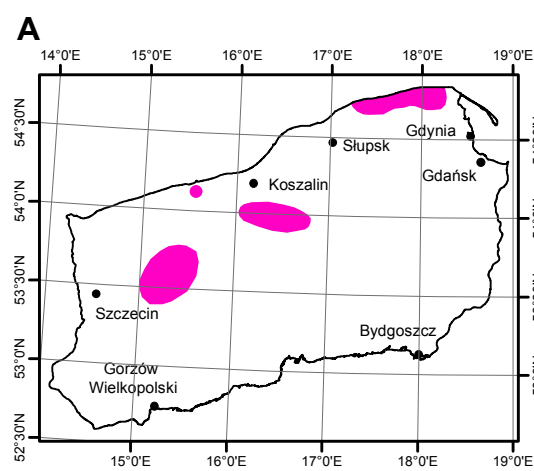

B
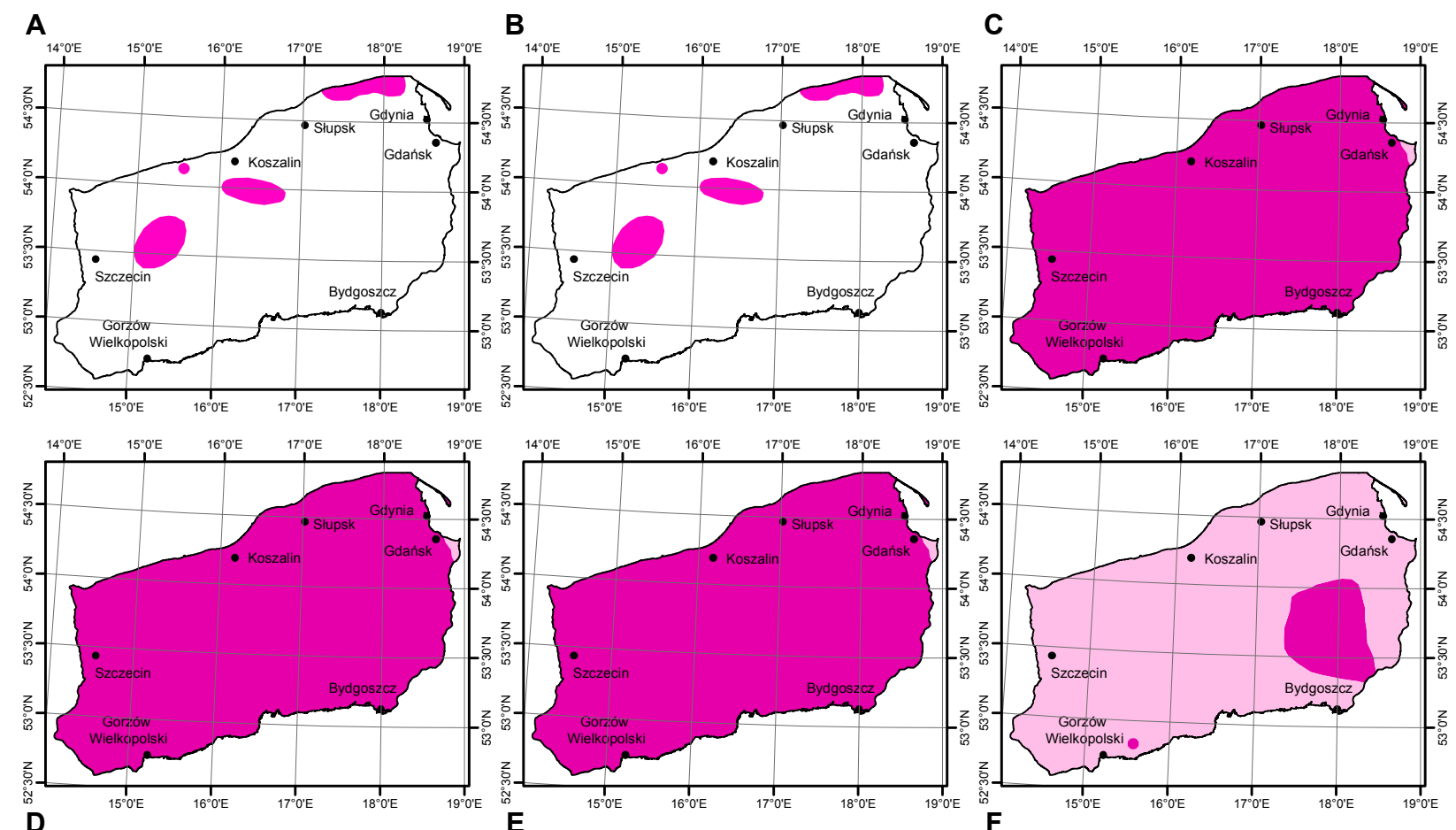

the actual occurrence (the continuous range or scattered sites) the potential occurrence

single and isolated actual sites

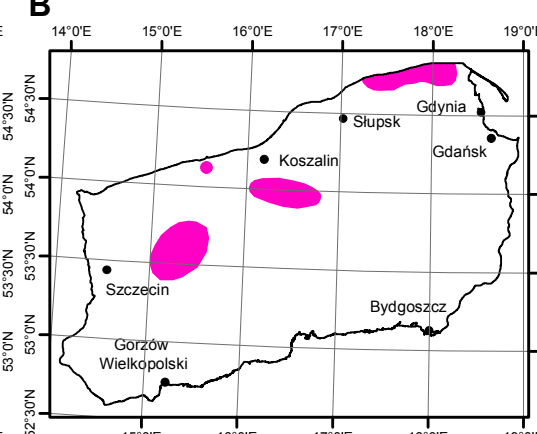

Figure 2. Geographic distribution of selected natural habitats in Pomerania together with subtypes according to Natura 2000 codes (A - 4010 wet heaths with cross-leaved heath Erica tetralix; B - 4010-1 wet heaths with cross-leaved heath Erica tetralix; C - 4030 dry heaths (Calluno-Genistion, Pohlio-Callunion, Calluno-Arctostaphylion); D - 4030-1 Genista heaths Calluno-Genistetum; E - 4030-2 heaths with Pohlia nutans Pohlio-Callunetum; F - 4030-3 bearberry heaths ArctostaphyloCallunetum)

\subsection{Spatial distribution of heaths according to the database of CORINE Land Cover}

Based on the analysis of resources of the CLC database, compiled for the year 2000, it appears that 20 heath areas (patches) were distinguished in Pomerania, with the total area of less than 1832 ha. All the identified sites are included within the category of peat bogs (code 412). The largest heathland, with the area of $235 \mathrm{ha}$, was located near the Słowiński National Park, and the smallest one (29 ha) - north-east of the Drawski Landscape Park. In the case of 12 heath sites, their area did not exceed 100 ha, and the area of the other 7 sites did not exceed $132 \mathrm{ha}$. The analysis of the CLC resources for the year 2006 did not distinguish any new heath sites and entirely confirmed the state of their occurrence for the year 2000. For the year 2000, also 20 heath sites were distinguished (Fig. 3) with the identical surface area and location.

\subsection{Spatial distribution of heaths according to questionnaires}

Among all 115 sent questionnaires, replies were received from more than 80 addressees. The analysis of the results permits the statement that heaths occur in the area of 28 forest divisions and one national park (the Tuchola Forest National Park). Table 1 presents the list of all forest divisions, where heath formations were recorded, whereas Figure 4 presents their spatial distribution. Altogether 4470 ha of heath areas were catalogued occurring at 480 sites. Most of the heathlands, in respect of the covered area, occur in the territory of:

- the Forest Division of Borne Sulinowo (over 1670 ha); they are classified within the so-called Kłomino heaths,

- the Forest Division of Drawsko (over 1370 ha), on the military training ground,

- the Forest Division of Czarnobór (over 240 ha),

- the Forest Division of Damnica (over 240 ha), 


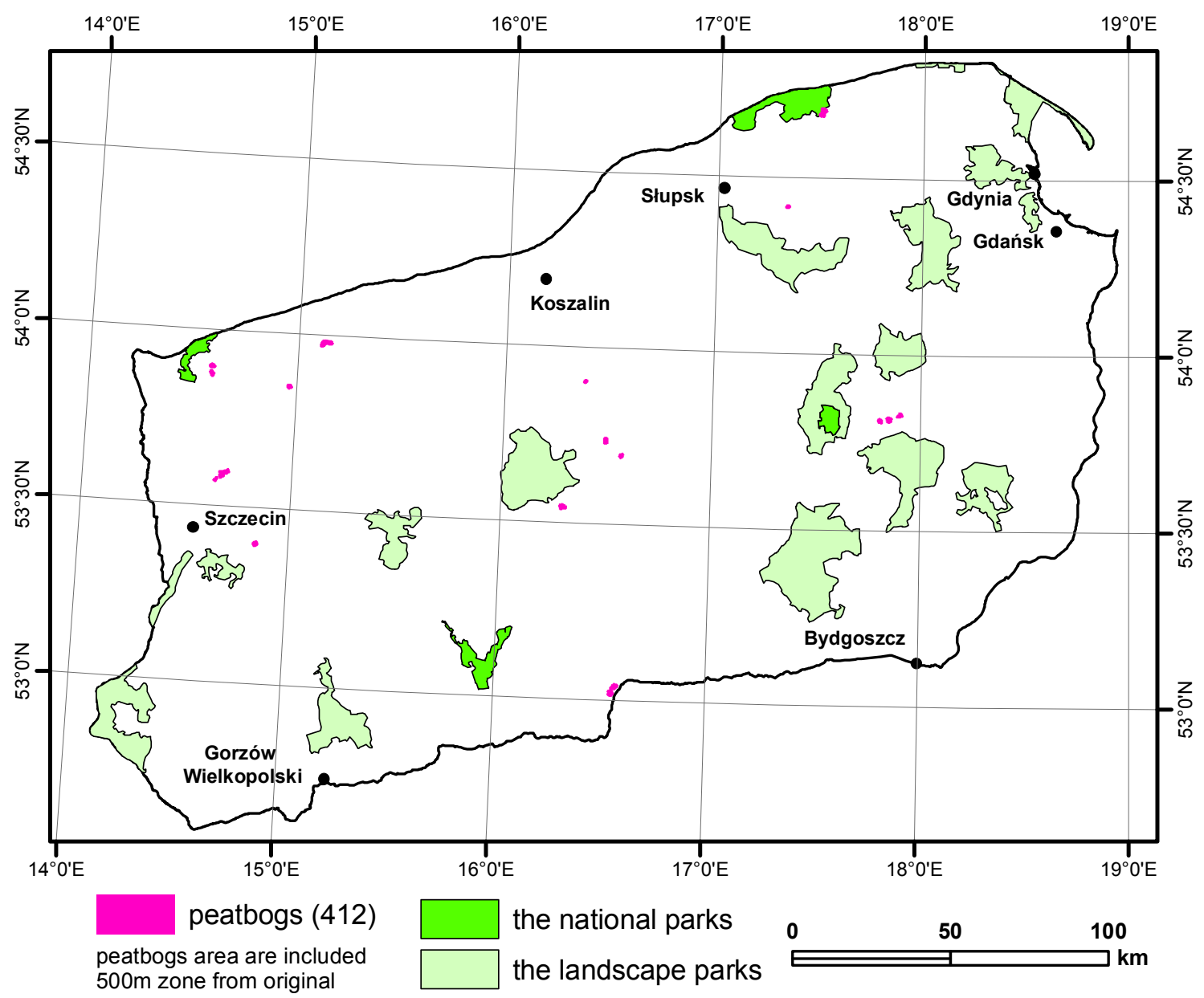

Figure 3. The occurrence of peat bogs in Pomerania according to the database of CORINE Land Cover from 2006

- the Forest Division of Okonek (over 200 ha); there are plans to create a nature reserve in this area.

The largest heather patches are located in the Forest Division of Borne Sulinowo (the forest districts of Borne Sulinowo and Broczyno), the Forest Divisions of Okonek (the forest district of Okonek) and Czarnobór (the forest district of Czarnobór).

Most of the heather patches are located in the Forest Division of Lubichowo (105), the Forest Division of Przymuszewo (139) and the Forest Division of Drawsko (80). However, the area of these heather patches is small. In the questionnaires Calluna vulgaris (included within dry heaths) was quoted as the only species encountered.

\section{Discussion and conclusions}

Heaths are not distinguished on contemporary topographic maps as a separate category of land cover/land use. On historical topographic maps, due to the nature of their ex- ploitation, they were included within poor grazing lands. Taking inventory of heaths was possible with the aid of methods based on satellite presentation or aerial photos. Based on the former source, the database CORINE Land Cover was created. However, due to the accepted methodology of delimitation of cover areas, heaths covering small areas (below $25 \mathrm{ha}$ ) could not be marked. A questionnaire seemed to be the only way to acquire the necessary information on the spatial distribution of heaths in Pomerania. Effectiveness of this method turned out to be at the level of less than $70 \%$. It means that not all heaths of this area were catalogued. However, based on the received questionnaires, details on heath areas in Pomerania were provided, what highly enriched the previous resources, including the CLC database. In the nearest future, new questionnaires are scheduled for forest divisions, from which no answers were received. Taking into account the fact that small but numerous heather patches dominate on the described area, these questionnaires may significantly influence the spatial distribution of heaths. 


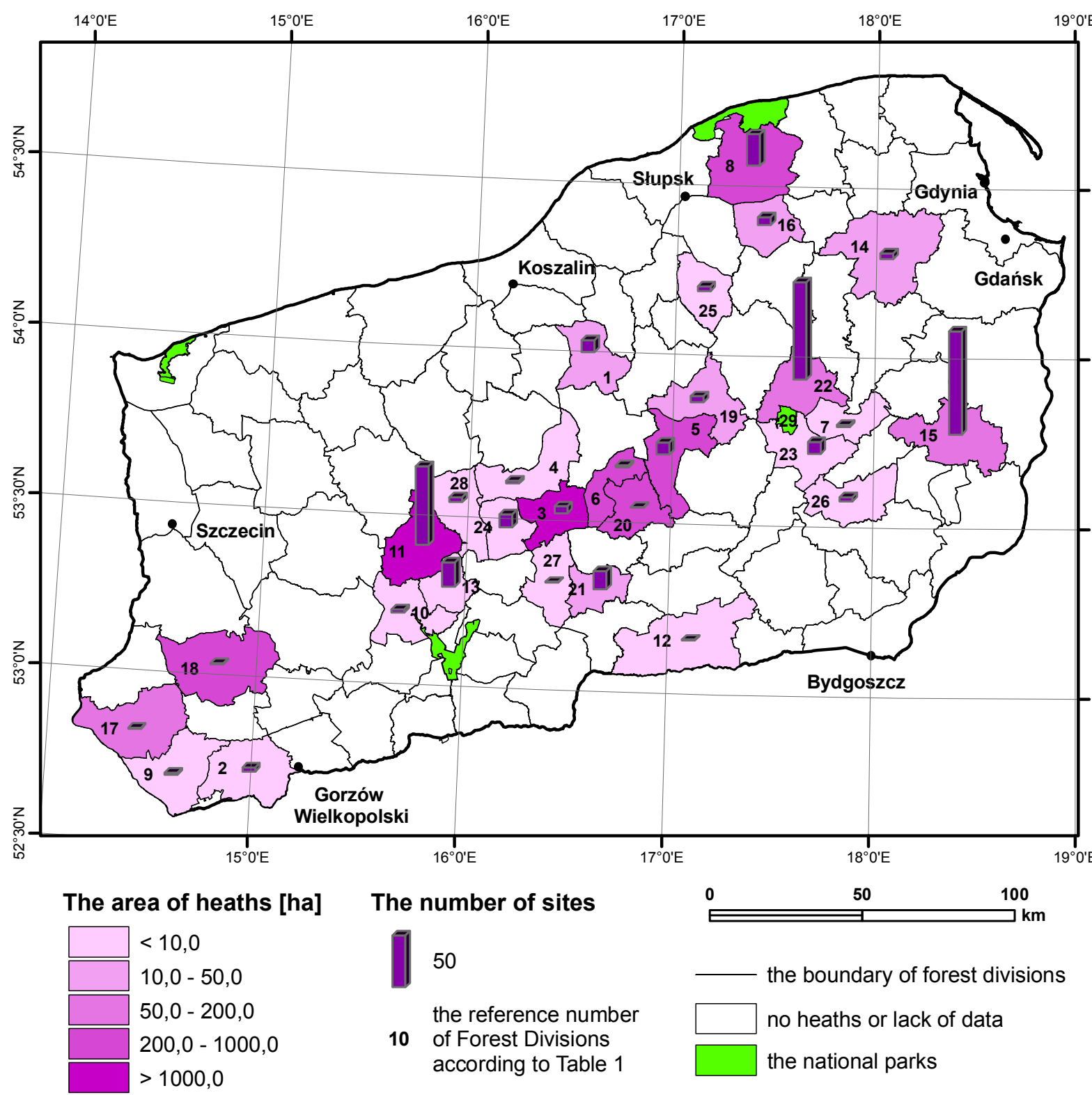

Figure 4. Spatial distribution of heaths, the total area and the number of sites in Pomerania with reference to forest divisions

At the same time, hopes for completing the inventory of heaths are connected with the completion of a forest numerical map after 11-years. All Forest Divisions in Poland have this kind of resources since March 2010.

The obtained results increase the knowledge on the heaths and their occurrence in Pomerania.

\section{Acknowledgements}

The project was being implemented within the framework of the grant by the Ministry of Science and Higher Educa- tion no. N N304 220835. The authors of this paper wish to extend their gratitude towards employees of all Forest Divisions and Directorates of national and landscape parks, who completed and sent back the questionnaire concerning the occurrence of heaths on areas under their administration. We are grateful to Ms Aleksandra Ruczyńska, MSc, for her assistance in entering the obtained information on the nature and economy into the database. 
Table 1. The surface area [ha] and the catalogued number of heather sites as per Forest Divisions based on the completed questionnaires

\begin{tabular}{|c|c|c|c|c|c|c|c|}
\hline $\begin{array}{l}\text { Refer- } \\
\text { ence } \\
\text { number }\end{array}$ & Forest Division & $\begin{array}{c}\text { Regional } \\
\text { Directorate of } \\
\text { State Forests }\end{array}$ & District & $\begin{array}{c}\text { The number } \\
\text { of heather } \\
\text { sites }\end{array}$ & $\begin{array}{c}\text { Total area } \\
\text { [ha] }\end{array}$ & $\begin{array}{l}\text { The largest } \\
\text { site [ha] }\end{array}$ & Remarks \\
\hline \multirow{2}{*}{1} & \multirow{2}{*}{ Bobolice } & \multirow{2}{*}{ Szczecinek } & Kurowo & 5 & 5.4 & 2.0 & \\
\hline & & & Kurowo & 7 & 10.9 & 3.0 & \\
\hline 2 & Bogdaniec & Szczecin & Mosina & 4 & 4.1 & 1.2 & $\begin{array}{c}\text { by the Friendship } \\
\text { pipeline }\end{array}$ \\
\hline \multirow{2}{*}{3} & \multirow{2}{*}{ Borne Sulinowo } & \multirow{2}{*}{ Szczecinek } & Borne Sulinowo & 2 & 711.5 & 710.6 & \multirow{2}{*}{$\begin{array}{c}\text { the so-called heaths } \\
\text { of Kłomino }\end{array}$} \\
\hline & & & Broczyno & 5 & 977.9 & 749.5 & \\
\hline 4 & Czaplinek & Szczecinek & Czaplinek & 3 & 0.3 & 0.2 & the military land \\
\hline 5 & $\begin{array}{c}\text { Czarne } \\
\text { Człuchowskie }\end{array}$ & Szczecinek & Czarne & 12 & 277.4 & 33.9 & \\
\hline 6 & Czarnobór & Szczecinek & Czarnobór & 2 & 242.7 & 128.1 & $\begin{array}{l}\text { the so-called heaths } \\
\text { of Kłomino }\end{array}$ \\
\hline 7 & Czersk & Toruń & Czersk & 2 & 1.5 & 1.0 & part of the reserve \\
\hline 8 & Damnica & Szczecinek & Główczyce & 32 & 242.5 & 35.9 & the ecological area \\
\hline 9 & Dębno & Szczecin & Dębno & 2 & 3.8 & 3.3 & \\
\hline 10 & Drawno & Szczecin & Drawno & 3 & 1.0 & 0.5 & \\
\hline 11 & Drawsko & Szczecinek & Drawsko & 80 & 1373.5 & 72.4 & \\
\hline 12 & Kaczory & Piła & Kaczory & 1 & 0.5 & 0.5 & \\
\hline 13 & Kalisz Pomorski & Piła & Kalisz Pomorski & 25 & 4.2 & 0.6 & \\
\hline \multirow{2}{*}{14} & \multirow{2}{*}{ Kartuzy } & \multirow{2}{*}{ Gdańsk } & Mirachowo & 1 & 0.1 & 0.1 & \\
\hline & & & Kartuzy & 5 & 12.0 & 4.7 & \\
\hline \multirow{3}{*}{15} & \multirow{3}{*}{ Lubichowo } & \multirow{3}{*}{ Gdańsk } & Drewniaczki & 26 & 36.5 & 4.9 & \\
\hline & & & Lubichowo & 35 & 40.1 & 3.8 & the ecological area \\
\hline & & & Osieczna & 44 & 67.0 & 3.7 & \\
\hline 16 & Łupawa & Szczecinek & Łupawa & 8 & 11.9 & 2.2 & \\
\hline 17 & Mieszkowice & Szczecin & Łysogórki & 1 & 72.0 & 72.0 & the nature reserve \\
\hline 18 & Myślibórz & Szczecin & Myślibórz & b.d. & b.d. & b.d. & the military land \\
\hline 19 & Niedźwiady & Szczecinek & Rudawa & 6 & 18.6 & 11.4 & \\
\hline 20 & Okonek & Piła & Okonek & 1 & 204.0 & 204.0 & $\begin{array}{l}\text { the designed nature } \\
\text { reserve }\end{array}$ \\
\hline 21 & Płytnica & Piła & Płytnica & 18 & 27.7 & 2.0 & \\
\hline \multirow{2}{*}{22} & \multirow{2}{*}{ Przymuszewo } & \multirow{2}{*}{ Toruń } & Laska & 59 & 19.2 & 1.1 & \\
\hline & & & Przymuszewo & 40 & 42.7 & 2.6 & \\
\hline \multirow{2}{*}{23} & \multirow{2}{*}{ Rytel } & \multirow{2}{*}{ Toruń } & Rytel & 3 & 0.1 & 0.0 & \\
\hline & & & Klosnowo & 9 & 1.8 & 0.9 & \\
\hline \multirow{2}{*}{24} & \multirow{2}{*}{ Świerczyna } & \multirow{2}{*}{ Szczecinek } & Nowy Dwór & 10 & 2.0 & 1.5 & at the forest burn site \\
\hline & & & Świerczyna & 3 & 6.9 & 4.2 & \\
\hline \multirow{2}{*}{25} & \multirow{2}{*}{ Trzebielino } & \multirow{2}{*}{ Szczecinek } & Trzebielino & 3 & 0.5 & 0.2 & \\
\hline & & & Wiatrołom & 2 & 1.8 & 0.6 & \\
\hline 26 & Tuchola & Toruń & Zalesie & 4 & 8.5 & 3.7 & \\
\hline 27 & Wałcz & Piła & Wałcz & 1 & 9.7 & 9.7 & \\
\hline 28 & Złocieniec & Szczecinek & Złocieniec & 5 & 0.5 & 0.1 & \\
\hline 29 & PNBT & & & 13 & 34.1 & 22.3 & \\
\hline
\end{tabular}




\section{References}

Augustowski B., 1977, Pomorze [Pomerania], Wydawnictwo PWN, Warszawa.

Bielecka E., 2007. Możliwości wykorzystania bazy danych o pokryciu terenu CORINE Land Cover do kartowania i analizowania krajobrazu [Potentialities of Using Corine Land Cover Databases for landscape Portrayal and Analyzing], [in:] K. Ostaszewska, I. Szumacher, S. Kulczyk, E. Malinowska (eds.) Znaczenie badań krajobrazowych dla zrównoważonego rozwoju [The Role of Landscape Studies for Sustainable Development], Wyd. UW, Warszawa.

Brzeg A., 1982, Sieglingio-Agrostetum ass. nova na drogach w borach sosnowych [Sieglingio-Agrostetum ass. nova on the roads in pine forests], Bad. Fizjogr. nad Polską Zach., Ser. B, 32: 157-165.

Ciołkosz A. \& Bielecka E., 2005, Pokrycie terenu w Polsce. Bazy danych CORINE Land Cover [Land Cover in Poland. Database CORINE Land Cover], Biblioteka Monitoringu Środowiska, Warszawa.

Czubiński Z., 1950, Zagadnienia geobotaniczne Pomorza [Geobotanical problems in Pomerania] Bad. Fizjogr. nad Polską Zach. 4 (2): 439-659.

Gawłowska J., 1964, Mącznica lekarska - Arctostaphylos uva-ursi L. w Polsce, jej zasoby i ochrona[Bearberry, Arctostaphylos uva-ursi L., in Poland, its resources and protection]. Ochrona Przyrody 30: 23-50.

Herbich J. (ed.), 2004, Murawy, łąki, ziołorośla, wrzosowiska, zarośla, Poradniki ochrony siedlisk i gatunków Natura 2000 - podręcznik metodyczny, tom 3 [Grasslands, meadows, tall herb vegetation, heaths, thickets, Methodical guides to conservation of habitats and species, Natura 2000, Volume 3], Ministerstwo Środowiska, Warszawa.

Herbichowa M., 1979, Roślinność atlantyckich torfowisk Pobrzeża Kaszubskiego [The vegetation of the Atlantic bogs on the Cashubian sea-coast], Soc. Sci. Ged., Acta Biologica 5: 1-51.

Jasnowski M., 1962a, Budowa i roślinność torfowisk Pomorza Szczecińskiego, Soc. Sc. Stetin., Wydz. Nauk
Przyr. Roln. 10. [Bauund Vegetation die Moore des Stettiner Pommerans], Soc. Sc. Stetin., Wydz. Nauk Przyr. Roln. 10.

Jasnowski M., 1962b, Torfowiska wrzosowiskowe typu atlantyckiego na Nizinie Szczecińskiej [Heather bogs of the Atlantic type in the Szczecin Lowlands], Bad. Fizjogr. nad Polską Zach. 10: 183-203.

Jasnowski M., Jasnowska J. \& Markowski S., 1968, Ginące torfowiska wysokie i przejściowe w pasie nadbałtyckim Polski [Vanishing raised peat bogs in the Baltic region of Poland], Ochrona Przyrody 33: 69-124.

Kunz M., Nienartowicz A. \& Mizgalska M., 2008, Przestrzenne rozmieszczenie wrzosowisk w Zaborskim Parku Krajobrazowym [Spatial distribution of heathlands in Zaborski Landscape Park], Wyd. Klubu Teledetekcji Środowiska PTG, Teledetekcja Środowiska 39: 111-118.

Markowski R., 1997, Zbiorowiska ze związku Empetrion nigri Böcher $1943 \mathrm{em}$. Schubert 1960 na polskim wybrzeżu Bałtyku Heaths of the Alliance Empetrion nigri Böcher 1943 em. Schubert 1960 on the Polish Baltic coast], [in:] W. Fałtynowicz, M. Latałowa, J. Szmeja (eds.) Dynamika i ochrona roślinności Pomorza [Dynamics and conservation of the Pomeranian vegetation], Bogucki Wyd. Nauk., Gdańsk-Poznań: 55-64.

Nienartowicz A. \& Kunz M., 2003, Polish heathlands, Abstract Book, 8th European Heathlands Workshop, Camp Reinsehlen, Schneverdingen, Germany: 50-54.

Piotrowska H. \& Herbich J., 1974, Zasadnicze kierunki wczesnych stadiów regeneracji spalonych torfowisk atlantyckich [Principal trends of early regeneration phases of burned peat bogs of Atlantic type], Phytocoenosis 3 (3/4): 227-238.

Veitch N., Webb N. R. \& Wyatt B. K., 1995, The application of Geographic Information Systems and remotely sensed data to the conservation of heathland fragments, Biological Conservation 72: 91-97.

Werdyn L., 1964, Materiały do rozmieszczenia Arctostaphylos uva-ursi L. na Niżu Polskim [Notes on distribution of Arctostaphylos uva-ursi L. in the Polish Lowlands], Bad. Fizjogr. nad Polską Zach. 14: 127-143. 